\title{
The Effect of Solution-Focused Brief Approach on Adolescent Subjective Well-Being: An Experimental Study
}

\author{
Bünyamin Ateş ${ }^{1}$
}

\begin{abstract}
The aim of this study is to examine the effect of solution-focused brief approach based on subjective well-being improvement program on adolescents' subjective well-being levels. The study group consisted of 36 adolescents with low subjective well-being pre-test scores. The research is a study based on true experimental design with pre-test which has experimental-control-placebo group, post-test and follow-up test measurements. In this study, Adolescent Subjective Well-Being Scale and Personal Information Form were used as data collection tools. Kruskal Wallis H Test for Independent Samples, Mann Whitney U Test for Independent Samples and Wilcoxon Signed Rank Test for Paired Samples were used to analyze data. According to obtained results, it was determined that there was a significant increase in subjective well-being post-test scores of adolescents in the experimental group compared to the pre-test scores, control and placebo groups. It was observed that the increase in the post-test scores of the adolescents in the experimental group was preserved in the follow-up measurements. In the control and placebo groups, no significant difference was found between the pre-test, post-test, and follow-up test scores.
\end{abstract}

Keywords: Adolescents, experimental study, subjective well-being, solution-focused brief approach, well-being.

\section{Introduction}

Man's effort to be good in the historical process has preserved its existence as one of its vital goals. Despite this, the focus was on negative functionality over the years and the absence of a mental problem. Symptom was seen as an indicator of mental health. The positive aspect of the individual were ignored (Myers \& Diener, 1995; Ryff, 1995; Ryff \& Singer, 1996; Ryff \& Singer, 2008; Springer \& Hauser, 2006). This perspective has changed over time with mental health perspectives that focus on the positive functionality of the individual. The well-being of the individual is given more importance. Well-being is considered as a broad expression of human potential in terms of mental, social, emotional and physical aspects (Ryyf \& Singer, 1998).

There are two approaches to well-being. These are respectively; eudaimonic and hedonic approaches. According to the eudaimonic approach, well-being defines as the state of the individual's full functioning in self-knowledge and self-actualization. Its conceptual counterpart in psychology is "psychological well-being". The hedonic approach is an approach that focuses on happiness, pleasure

${ }^{1}$ Assoc. Prof. Dr., Erzincan Binali Yıldırım University, Turkey, bunyaminates81@gmail.com, ORCID: 0000-0003-40901922 
and avoiding pain. According to this approach, well-being is equivalent to happiness and pleasure. From this point of view, well-being extends from physical pleasure to interests. Its conceptual counterpart in psychology is "subjective well-being" (Ryan \& Deci, 2001; Ryff \& Singer, 2008).

Subjective well-being emerged as a result of the search for quality life. It is formulated as life satisfaction and happiness. Subjective well-being is the assessment of balance and satisfaction between the positive and negative effects of life. Subjective well-being is a concept about how someone evaluates his life or how he adds value to his life (Diener el al., 1997; Diener el al., 2017). Subjective well-being is the assessment of one's own life cognitively and affectively (Diener \& Diener, 1996).

Subjective well-being consists of two dimension; affect (positive and negative affect) and cognitive (life satisfaction) components. In terms of components, a subjective assessment is made. Affective evaluation with regards to positive and negative affect, and cognitive evaluation according to life satisfaction. Subjective well-being, positive affect, frequent and high level of experience. In contrast, it also involves a less frequent, low level of negative affect and a high level of life satisfaction (Diener el al., 1999; Diener el al., 2017; Myers \& Diener, 1995; Tov \& Diener, 2007).

Positive affect reflects the appearance of various positive emotions together, such as the joy, excitement, interest, pleasure, alertness and trust that people experience when good things happen in their lives. In contrast, negative affect experienced as subjective distress and discontent; it reflects the appearance of negative emotions that people do not desire in their lives, such as anger, stress, anxiety, fear, sadness, guilt, and disdain. These affect can be instant and long-lasting. The cognitive component of reflects the life satisfaction of the person to evaluate their own life according to the standards determined subjectively (Ben-Zur, 2003; Diener el al., 2017; Schimmack el al., 2002).

A person with a high level of subjective well-being experiences more often positive emotions while less negative experiences. As a result, the person has a high life satisfaction as a whole. Individuals with high level of subjective well-being evaluate positive ongoing life events and therefore experience more pleasant emotions. On the other hand, individuals with low levels of subjective well-being; they negatively evaluate ongoing life events and conditions. Therefore, those might be experiencing less positive emotions, more often unpleasant affect experiences and the ones' life satisfaction are also low (Diener el al., 1997; Myers \& Diener, 1995; Tov \& Diener, 2007).

Studies on subjective well-being gained weight after the second half of the twentieth century and research was carried out in the context of who, what and how in the historical process. In other words, "Who is a happy person?" "What makes people happy?" "How do various factors relate to happiness?" Answers such as questions were sought (Diener, 1984; Myers \& Diener, 1995; Rice \& Steele, 2004; Tov \& Diener, 2007). When studies on subjective well-being were examined, it was observed that there were studies mainly related to variable of subjective well-being or focused on variables that might affect subjective well-being. Although these researches are important in terms of understanding the subjective well-being better, it is noteworthy that there are limited number of experimental studies on the subject and it is not based on an approach mostly in the experimental studies conducted. In addition, experimental studies based on solution-focused brief approach to improve the subjective well-being level of adolescents have not been found. In this context, this experimental study, which examines the effect of one of the postmodern approaches, subjective well-being based on solution-focused brief approach, is considered to be important and useful for the field. 
The solution-focused brief approach emerged as one of the postmodern approaches in the last quarter of the 20th century under the roof of "Brief Therapy" in the USA. There are three factors that led to the emergence of this approach. These are respectively the works of Milton Erickson, the studies conducted in the center of Mental Research Institute and the studies conducted in Brief Family Therapy Center. Steve de Shazer, Insoo Kim Berg, Bill O'Hanlon, Michelle Weiner-Davis, Scott Miller, John Walter and Jane Peller are among the pioneers of the solution-focused brief approach. In this approach, the nature and origin of the problem experienced by individuals are not concerned. Problems are not labeled as a pathological condition. Instead of researching the source of the problem, emphasis is placed on solutions, strengths, successes and resources. In the process, a solution-focused language structure is used, and in this context, it is given importance to form goals in a specific, small, positive way and to be meaningful for the individual. Solution-focused brief approach is now and future oriented. The past is valuable only when there are successes and solutions (exceptional moments). In this approach, it is aimed to continue past and present useful successes and posible solutions in the future. In this approach, number of sessions is usually less than ten sessions (De Shazer, 1985; De Jong \& Berg, 1998; Murphy, 1997; Iveson, 2002; O'Connell, 2001; Sparrer, 2012). Main techniques specific to the solutionfocused brief approach are: miracle question technique, crystal ball technique, formulization of first session task, pre-session change technique, exception situations, coping questions technique, scaling questions, nightmare question technique (Ateş, 2018; De Shazer, 1985; De Shazer \& Berg, 1997; De Jong \& Berg, 1998; Lethem, 2002; Murdock, 2012; Murphy, 1997).

It can be said that an individual with a subjective well-being experience more positive can experience positive emotions more often and has a higher level of life satisfaction as well as less negative affect. In fact, this may be a desired lifestyle for individuals. Although it is desired that individuals have positive emotions more intensely and frequently throughout their lives and have a higher level of life satisfaction, it is thought to be more important in adolescence, which is a critical period in terms of development periods. Considering that the positive and negative aspects of this period, which is a critical period, also affect the later stages of life, for an adolescent with a high level of subjective wellbeing, this may positively affect not only his current life but also his later life. A young person with a high level of subjective well-being can achieve a high level of functionality in different areas of life with an improvement in quality of life. At this point, studies to improve subjective well-being of adolescents are considered to be useful and important. Purpose of the study conducted in line with this idea is to examine the effect of solution-focused brief approach based on subjective well-being improvement program on adolescents' subjective well-being levels. For this purpose, in the study, "Is the program of improving subjective well-being based on solution-focused brief approach effective on subjective wellbeing levels of adolescents?" The answer to the question was sought.

\section{Method}

\section{Research Models}

The research is based on true experimental design with pre-test which has experimental-control-placebo group, post-test and follow-up test measurement. True experimental designs are the ones with the highest scientific value. The common features of these models are the use of multiple groups and the creation of groups with randomly assignment. Groups are considered equal in terms of other control 
variables (Büyüköztürk el al., 2013; Karasar, 2016). In this study, the independent variable is the implementation of the program developed based on a solution-focused brief approach. The dependent variable is the subjective well-being scores of the students. The experimental design of the study is presented in Table 1.

Table 1

Experimental Design of the Study

\begin{tabular}{lcllll}
\hline Group & N & Pre-test & Implementation & \multicolumn{2}{l}{$\begin{array}{l}\text { Post-test/Follow- } \\
\text { up test }\end{array}$} \\
\hline Experimental & 12 & $\begin{array}{l}\text { Adolescent } \\
\text { Subjective Well- } \\
\text { Being Scale }\end{array}$ & $\begin{array}{l}\text { Solution-focused brief approach based } \\
\text { on program of improving subjective } \\
\text { well-being }\end{array}$ & $\begin{array}{l}\text { Adolescent } \\
\text { Subjective } \\
\text { Being Scale }\end{array}$ & Well- \\
\hline Control & 12 & $\begin{array}{l}\text { Adolescent } \\
\text { Subjective Well- } \\
\text { Being Scale }\end{array}$ & No implementation has been made & $\begin{array}{l}\text { Adolescent } \\
\text { Subjective } \\
\text { Being Scale }\end{array}$ & Well- \\
\hline Placebo & 12 & $\begin{array}{l}\text { Adolescent } \\
\text { Subjective Well- } \\
\text { Being Scale }\end{array}$ & $\begin{array}{l}\text { A program that is different from the } \\
\text { experimental group and has no effect } \\
\text { on subjective well-being. }\end{array}$ & $\begin{array}{l}\text { Adolescent } \\
\text { Subjective } \\
\text { Being Scale }\end{array}$ & Well- \\
& & & & & \\
\end{tabular}

\section{Study Group}

The study group of this research consists of 36 adolescents with low subjective well-being pre-test scores among 286 adolescents who continue their education in a high school in Erzincan in 2018-2019 academic year and want to participate in the experimental study. The groups consist of 12 people (experimental group: 6 girls, 6 boys; control group: 5 girls, 7 boys; placebo group: 7 girls; 5 boys). The age range varies between 14-18. The average age of the study group is 16.41 .

\section{Data Collection Tools}

\section{Adolescent Subjective Well-Being Scale}

The scale was developed by Eryllmaz (2009) with the aim of measuring the subjective well-being of adolescents between 14-18 years of age. The scale is a quartile rating scale consisting of 15 items and four dimensions (Satisfaction with family relationships, important satisfaction with others, life satisfaction and positive emotions). The higher the score on the scale, the higher the level of subjective well-being. Factor analysis of the scale revealed that four factors accounted for $61.64 \%$ of the total variance. $35.79 \%$ of the explained variance was explained by satisfaction with family relations, $9.70 \%$ with satisfaction with significant others, $8.69 \%$ with life satisfaction and $7.44 \%$ with positive affective subscales. Substance factor loads range from .63 to .79 . The Cronbach alpha internal consistency reliability coefficients were .86 for all dimensions, .83 for satisfaction with family relationships, .73 for satisfaction with significant others, .81 for life satisfaction, and .66 for positive emotions. Spearman Brown reliability coefficients were found to be .83 for satisfaction with the scale, .83 for satisfaction with family relationships, .61 for satisfaction with significant others, .79 for life satisfaction, and .54 for positive feelings. The test-retest reliability coefficient of the scale was .83 (Eryılmaz, 2009). In this study, Cronbach Alpha reliability coefficient was determined to be .88 for the whole scale. 


\section{Personal Information Form}

Personal information form was created based on the principle of confidentiality within the scope of this research so as to learn the personal information of the adolescents that make up the study group.

\section{Data Analysis}

In the analysis of the data obtained in this study, it was first examined whether the data had a parametric value and it was determined that the normality assumption was not met for the parametric statistics. In the analysis of the data obtained in this context, Kruskal Wallis H Test for Independent Samples, Mann Whitney U Test for Independent Samples and Wilcoxon Signed Rank Test for Paired Samples were used. Data analyzes were carried out in computer environment through SPSS programs. In the study, .05 level of significance was accepted (Büyüköztürk, 2011).

\section{Process}

In this study, the purpose of the study firstly was explained to adolescents with a positive and solutionfocused language structure without labeling others. "Adolescent Subjective Well-Being Scale" and "Personal Information Form" were applied to 286 adolescents who volunteered to participate in the study. Later, 36 adolescents who volunteered to participate in the study were determined in the preliminary interviews conducted in accordance with the occupational ethics of the field with a low adolescent subjective well-being pre-test score. These 36 adolescents were randomly distributed to groups, with 12 people in each group. After that, these groups were selected randomly as experimental, control and placebo groups. Solution-focused brief approach based on subjective well-being improvement program was applied to the adolescents in the experimental group for six sessions. The sessions were conducted once a week for an average of 90 minutes. A program consisting of six sessions (natural, social problems and solutions) was applied to adolescents in the placebo group, which is different from the program applied to the experimental group and has no effect on their subjective wellbeing. The sessions were conducted once a week for an average of 90 minutes. The adolescents in the control group were allowed to continue their normal education activities without any action. After the planned group session processes were completed, post-test (adolescent subjective well-being scale) was applied to all three groups. Eight weeks after the post-test measurements, follow-up measurements were made to determine the permanence of the experimental process. At the end of the study, a 90minute seminar on subjective well-being was given to adolescents in the control and placebo group in accordance with occupational ethics.

\section{Development of the Program and Implementation Process}

For the development of targeted programs, firstly solution-focused brief approach and subjective wellbeing studies in Turkey and abroad were studied. Then, a program framework based on a solutionfocused brief approach was created. After creating the framework of the program, a study of four sessions was carried out with 10 adolescents in the high school in the scope of the preliminary trial of the program. In the preliminary trial, deficiencies of the program were found and the program was made suitable for the study group. 
The program process was briefly carried out as follows:

Session I: Meeting and Purposes: (In this session: The group leader and members met. Members were informed about the program, the purpose of the program, and the solution-focused approach. Group rules were created. The members were asked to positively express their expectations and goals in the group process. Evaluations were made (scaling questions). Sharing was made about pre-session change. Homework was given based on formulization of first session task. The session was terminated.

Session II: Miracles (In this session: Sharing was made about the formulation of the first session task. The activity of "My miracle" was applied. Based on this activity, positive expectations were created to raise the level of subjective well-being. Homework was given to realize the experiences that support miracles). Evaluations were made (scaling questions). The session has been terminated.

Session III: Exceptions (In this session: Sharing was done about homework. The "My exceptions" activity was implemented. Homework was given to raise the level of subjective well-being, and to focus on experiences that improve positive emotions. Evaluations were made (scaling questions) and the session was ended.

Session IV: Solutions and Resources (In this session: Sharing about homework was done. "Solutions and resources" activity was implemented. Homework about useful solutions and resources was given. Evaluations were made (scaling questions) and the session was ended.

Session V: Designing the Future in a Positive Way (In this session: Sharing about useful resources and solutions has been made. The event "I in the future" has been implemented. Sharing has been made on what can be done to achieve the positive future designed. Evaluations were made (scaling questions) and the session was ended.

Session VI: Termination (In this session: A general evaluation of the group process was made. Gains and changes were discussed. Individual evaluations were made by taking the feelings and thoughts of the members of the group process. After the evaluations, the group process was terminated.

\section{Findings}

In this study, it was first examined whether there was a significant difference between the adolescent subjective well-being pre-test scores of the groups. The pre-test scores of the groups were analyzed with the Kruskal Wallis H Test for Independent Samples. As a result of the analysis, there was no significant difference between the pre-test scores of the groups $\chi 2(\mathrm{df}=2, \mathrm{n}=36)=.483, p>.05$. Kruskal Wallis H Test for Independent Samples analysis results related to the pre-test scores of the groups are given in Table 2.

Table 2

Kruskal Wallis H-Test for Independent Samples Analysis Results Related to the Pre-test Scores of the Groups

\begin{tabular}{lllllc}
\hline Group & $\mathrm{N}$ & Mean Rank & $\mathrm{df}$ & $\chi^{2}$ & $p$ \\
\hline Experimental & 12 & 17.13 & 2 & .483 & .785 \\
Control & 12 & 18.38 & & & \\
Placebo & 12 & 20.00 & & & \\
\hline
\end{tabular}

After determining that there was no significant difference between the pre-test scores of the groups, it was examined whether there was a significant difference between the groups' adolescent subjective 
well-being post-test scores. Post-test scores of the groups were analyzed with the Kruskal Wallis H Test for Independent Samples and the results are presented in Table 3.

Table 3

Kruskal Wallis H-Test for Independent Samples Analysis Results Related to the Post-test Scores of the Groups

\begin{tabular}{lllllll}
\hline Group & $\mathrm{N}$ & Mean Rank & $\mathrm{df}$ & $\chi^{2}$ & $p$ & $\begin{array}{l}\text { Significant } \\
\text { Difference }\end{array}$ \\
\hline Experimental & 12 & 30.42 & 2 & 23.15 & .000 & A-B, A-C \\
Control & 12 & 12.38 & & & & \\
Placebo & 12 & 12.71 & & & & \\
\hline
\end{tabular}

$\mathrm{A}=$ Experimental Group, B= Control Group, $\mathrm{C}=$ Placebo Group

When Table 3 is examined, it is seen that there is a significant difference between the post-test scores of the groups $\chi^{2}(\mathrm{df}=2, \mathrm{~N}=36)=23.15, p<.05$. Mann Whitney $\mathrm{U}$ Test for Independent Samples was used to determine the source of the difference. According to the analysis, the subjective well-being scores of the adolescents in the experimental group were higher according to mean rank than the control and placebo groups, and the differences were significant as well. In addition to these analyzes, whether there is a significant difference between the pre-test scores and post-test scores of the groups was analyzed with the Wilcoxon Signed Rank Test for Paired Samples and the results are presented in Table 4.

Table 4

Wilcoxon Signed Rank Test for Paired Samples Analysis Results Related to Pre-Test and Post-Test Scores of the Groups

\begin{tabular}{|c|c|c|c|c|c|c|}
\hline $\begin{array}{l}\text { Post-test/ } \\
\text { Pre-test }\end{array}$ & & $\mathrm{N}$ & $\begin{array}{l}\text { Mean } \\
\text { Rank }\end{array}$ & $\begin{array}{l}\text { Sum of } \\
\text { Ranks }\end{array}$ & $z$ & $p$ \\
\hline \multirow[t]{2}{*}{$\begin{array}{l}\text { Experimental } \\
\text { Group }\end{array}$} & $\begin{array}{l}\text { Negative } \\
\text { Ranks }\end{array}$ & 0 & .00 & .00 & -3.06 & .002 \\
\hline & $\begin{array}{l}\text { Positive } \\
\text { Ranks } \\
\text { Ties }\end{array}$ & 12 & 6.50 & 78.00 & & \\
\hline \multirow[t]{2}{*}{$\begin{array}{l}\text { Control } \\
\text { Group }\end{array}$} & $\begin{array}{l}\text { Negative } \\
\text { Ranks }\end{array}$ & 6 & 5.33 & 32.00 & -.466 & .641 \\
\hline & $\begin{array}{l}\text { Positive } \\
\text { Ranks } \\
\text { Ties }\end{array}$ & 4 & 5.75 & 23.00 & & \\
\hline \multirow[t]{2}{*}{$\begin{array}{l}\text { Placebo } \\
\text { Group }\end{array}$} & $\begin{array}{l}\text { Negative } \\
\text { Ranks }\end{array}$ & 6 & 6.67 & 40.00 & -.632 & .528 \\
\hline & $\begin{array}{l}\text { Positive } \\
\text { Ranks } \\
\text { Ties }\end{array}$ & 5 & 5.20 & 26.00 & & \\
\hline
\end{tabular}

According to the results of Wilcoxon Signed Rank Test for Paired Samples of the pre-test scores and post-test scores of the groups; there was no significant difference between the pre-test scores and posttest scores of the control group $(z=-.466, p>.05)$ and placebo group $(z=-.632, p>.05)$. Moreover, analysis results shows that there is a significant difference between the pre-test scores and post-test scores of the experimental group $(z=-3.06, p<.05)$. When the mean rank and sum of ranks of the difference scores are taken into consideration, it is seen that this difference is in favor of positive ranks, post-test scores.

In order to determine the permanence of this significant level difference in favor of the post-test scores of the experimental group and the experimental group, the groups were followed up at eight weeks after the post-test measurements. It was examined whether there was a significant difference between 
the groups' follow-up test scores of subjective well-being. The follow-up test scores of the groups were analyzed with the Kruskal Wallis $\mathrm{H}$ Test for Independent Samples and the results obtained are presented in Table 5.

Table 5

Kruskal Wallis H Test for Independent Samples Analysis Results Related to Follow-up Test Scores of the Groups

\begin{tabular}{|c|c|c|c|c|c|c|}
\hline Group & $\mathrm{N}$ & Mean Rank & df & $\chi^{2}$ & $p$ & $\begin{array}{l}\text { Significant } \\
\text { Difference }\end{array}$ \\
\hline Experimental & 12 & 30.46 & 2 & 23.55 & .000 & A-B, A-C \\
\hline Control & 12 & 11.54 & & & & \\
\hline Placebo & 12 & 13.50 & & & & \\
\hline
\end{tabular}

$\mathrm{A}=$ Experimental Group, $\mathrm{B}=$ Control Group, $\mathrm{C}=$ Placebo Group

When Table 5 is examined, it is seen that there is a significant difference between the follow- up test scores of the groups $\chi^{2}(\mathrm{df}=2, \mathrm{~N}=36)=23.55, p<.05$. Mann Whitney $\mathrm{U}$ Test for Independent Samples was used to determine the source of the difference. According to the analysis, the subjective well-being scores of the adolescents in the experimental group were higher according to mean rank than the control and placebo groups, and the differences were significant as well. These findings showed that the difference in favor of the experimental group in the post-test scores continued in the follow-up test. In addition to these analyzes, whether there is a significant difference between the post-test scores of the groups and the follow-up test scores was analyzed with the Wilcoxon Signed Rank Test for Paired Samples and the results are presented in table 6.

Table 6

Wilcoxon Signed Rank Test for Paired Samples Analysis Results Related to the Post-Test and Follow-up Test Scores of the Groups

\begin{tabular}{|c|c|c|c|c|c|c|}
\hline $\begin{array}{l}\text { Follow-up } \\
\text { Test/ Post-test }\end{array}$ & & $\mathrm{N}$ & $\begin{array}{l}\text { Mean } \\
\text { Rank }\end{array}$ & $\begin{array}{l}\text { Sum of } \\
\text { Ranks }\end{array}$ & $\mathrm{z}$ & $p$ \\
\hline \multirow[t]{2}{*}{$\begin{array}{l}\text { Experimental } \\
\text { Group }\end{array}$} & $\begin{array}{l}\text { Negative } \\
\text { Ranks }\end{array}$ & 4 & 5.00 & 20.00 & -.788 & .431 \\
\hline & $\begin{array}{l}\text { Positive } \\
\text { Ranks } \\
\text { Ties }\end{array}$ & $\begin{array}{l}6 \\
2 \\
\end{array}$ & 5.83 & 35.00 & & \\
\hline \multirow[t]{2}{*}{$\begin{array}{l}\text { Control } \\
\text { Group }\end{array}$} & $\begin{array}{l}\text { Negative } \\
\text { Ranks }\end{array}$ & 7 & 4.64 & 32.50 & -.520 & .603 \\
\hline & $\begin{array}{l}\text { Positive } \\
\text { Ranks } \\
\text { Ties }\end{array}$ & $\begin{array}{l}3 \\
2 \\
\end{array}$ & 7.50 & 22.50 & & \\
\hline \multirow[t]{2}{*}{$\begin{array}{l}\text { Placebo } \\
\text { Group }\end{array}$} & $\begin{array}{l}\text { Negative } \\
\text { Ranks }\end{array}$ & 5 & 4.40 & 22.00 & -.570 & .569 \\
\hline & $\begin{array}{l}\text { Positive } \\
\text { Ranks } \\
\text { Ties }\end{array}$ & $\begin{array}{l}5 \\
2 \\
\end{array}$ & 6.60 & 33.00 & & \\
\hline
\end{tabular}

According to the results of Wilcoxon Signed Rank Test for Paired Samples of the post-test scores and follow-up test scores of the groups; there was no significant difference between the post-test scores and follow-up test scores of the experimental group $(z=-.788, p>.05)$, control group $(z=-.520, p>.05)$ and placebo group $(z=-.570, p>.05)$. These findings show that the increase in subjective well-being scores of 
adolescents in the experimental group was also preserved in the follow-up test and that the solutionfocused brief approach based on subjective well-being improvement program was effective in raising the subjective well-being levels of adolescents.

\section{Discussion}

In this study, which was conducted to examine the effect of solution-focused brief approach based on subjective well-being improvement program on adolescents' subjective well-being levels, it was first examined whether there was a significant difference between the groups' subjective well-being pre-test scores. According to the findings, there was no significant difference between the pretest scores of the groups.

This result is important to determine the effect of program applied to the experimental group. Thus, the significant difference in favor of the post-test scores of the experimental group and the experimental group can be attributed to the effect of the program applied to the experimental group. In order to determine the effect of program, a solution focused brief approach based on subjective well-being improvement program was applied to adolescents in the experimental group, and a program that had no effect on their subjective well-beings and was different from the program applied to the experimental group for adolescents in the placebo group was applied. On the other hand, adolescents in the control group were allowed to continue their normal educational activities without any action. After the group session processes were completed, post-test (adolescent subjective well-being scale) was applied to all three groups. Eight weeks after the post-test measurements, follow-up measurements and data analyzes were performed to determine the permanence of the experimental process.

Concequently; It was determined that there was a significant increase in subjective well-being post-test scores of adolescents in the experimental group compared to pre-test scores, control and placebo groups. As a result of the study, it was observed that the increase in the post-test scores of adolescents in the experimental group was preserved in the follow-up measurements performed eight weeks after the post-test measurements. Conversely, In the control and placebo groups, no significant difference was found between the pre-test, post-test, and follow-up test scores. After all process, it was determined that the program of improving the subjective well-being based on solution-focused brief approach was effective in raising the subjective well-being levels of adolescents in the experimental group and this effect was also preserved in follow up measurements. This change in the experimental group was supported by verbal feedback from adolescents.

These results show that the solution-focused brief approach based on subjective well-being improvement program is effective in raising the subjective well-being levels of adolescents. Based on this study and other study results, it can be said that the subjective well-being levels of individuals can be increased. Although it is seen that individuals' subjective well-being levels are increased with the various programs applied when the literature is examined, it is noteworthy that the studies are mostly not based on an approach. (Dubé, Lapierre, Bouffard, \& Alain, 2007; Ergin, Eren, \& Tatlı, 2020; Ery1lmaz, 2014; Karataş, 2014; Malkoç, 2011; Sağkal \& Türnüklü, 2017; Saito, Kai, \& Takizawa, 2012; Shapiro \& Taylor, 2002). In particular, experimental studies based on solution-focused brief approach to increase the subjective well-being level of adolescents have not been found. 
This program, which is developed and implemented as well, is effective in raising the subjective wellbeing levels of adolescents; it is thought that the implementation of the program based on a solutionfocused brief approach is also an important factor. Because optimism and positivity are the basis of this approach. In this context, solutions, strengths, successes and resources are valued. Focus is on the future and now. Past is considered valuable for times when past solutions are produced and there are successes. It is aimed to sustain the current achievements and solutions in the future in the past.

At this point, when the studies based on solution-focused brief approach are examined, peer bullying of students in experimental studies (Arslan \& Akın, 2016); depression (Sarı \& Günaydın, 2016), school burnout (Ateş, 2016a; Nedim Bal \& Kaya, 2017), social phobia (Ateş \& Gençdoğan, 2017), aggressive behavior (Fitriyah, 2017), test anxiety (Altundağ \& Bulut, 2019) has been shown to be effective in reducing levels. Besides, assertiveness skills (Ateş, 2015), self-efficacy (Sarvi \& Ghazi, 2016; Yılmaz Bingöl \& Akın, 2018), perceived social competence (Ateş, 2016b), learning motivation (Setiono, Marjohan \& Marlina, 2019), academic resilience (Hendar, Awalya \& Sunawan, 2020) and improving self-concept (Novriansyah, Purwanto \& Wibowo, 2020) were found to be effective in raising levels. As can be understood from these studies, experimental studies based on a solution-focused brief approach is an effective approach for students to continue their lives with a better, high quality, desired quality and a high level of functionality.

In short, studies based on this approach contribute to a more positive life for individuals. Considering the results of the literature review as a whole, it is possible to say that the level of subjective well-being can be increased and that programs based on solution-focused brief approach are effective in many issues. In this study, it was determined that the program of increasing the subjective well-being based on solution-focused brief approach was effective in raising the subjective well-being levels of adolescents. It can be said that an adolescent with a subjective well-being experience experiences more positive affect while experiencing less negative affect and a high level of life satisfaction.

In this context, it is important to determine the variables that are related to the subjective well-being levels of adolescents and that may affect their subjective well-being levels, yet it is also important in studies aimed at improving their subjective well-being level. It can be said with these studies that functionality of adolescents in different areas of life can be improved by increasing their subjective wellbeing levels. This situation of the adolescent who has a high level of subjective well-being may affect his or her later life process positively and this effect may continue for life. In short, it is thought that a positive effect can be created in the lives of adolescents now and in the future by increasing the subjective well-being level.

At this point, the following suggestions can be made: The content of the program developed in this study can be adapted to individuals with different characteristics by changing the content. Programs based on other approaches to increase the level of subjective well-being can be developed. In schools, it is possible to place more studies (such as seminars, program development and implementation) to protect and raise the level of subjective well-being of students, as well as to raise awareness among parents and teachers. Based on both the results of this study and other studies based on a solutionfocused brief approach, a solution-focused brief approach can be used more in the field of mental health. 


\section{References}

Altundağ, Y., \& Bulut, S. (2019). The effect of solution-focused brief counseling on reducing test anxiety. $\begin{array}{llll}\text { Avances en Psicología Latinoamericana, 37(1), 1-11. DOI: } & \end{array}$ http://dx.doi.org/10.12804/revistas.urosario.edu.co/apl/a.6270.

Arslan, N., \& Akın, A. (2016). Çözüm odaklı kısa süreli grupla psikolojik danışmanın lise öğrencilerinin akran zorbalığına etkisi. Sakarya University Journal of Education,6(1), 72-84. DOI: http://dx.doi.org/10.19126/suje.62580.

Ateş, B. (2015). Üniversite öğrencilerinin güvengenlik becerileri üzerinde çözüm odaklı grupla psikolojik danışmanın etkisi. Mersin Üniversitesi Ĕ̆itim Fakültesi Dergisi, 11(3), 832-841. DOI: 10.17860/efd.84626.

Ateş, B. (2016a). Effect of solution focused group counseling for high school students in order to struggle with school burnout. Journal of Education and Training Studies, 4(4), 27-34. DOI: 10.11114/jets.v4i4.1254.

Ateş, B. (2016b). The effect of solution focused brief group counseling upon the perceived social competences of teenagers. Journal of Education and Training Studies, 4(7), 28-36. DOI: 10.11114/jets.v4i7.1443.

Ateş, B., \& Gençdoğan, B. (2017). Üniversite öğrencilerinin sosyal fobi ile başa çımalarında çözüm odaklı grupla psikolojik danışmanın etkisinin incelenmesi. İnönü Üniversitesi Eğitim Fakültesi Dergisi, 18(1), 188-203. DOI: 10.17679/inuefd.306513.

Ateş, B. (2018). Çözüm odaklı kısa süreli psikolojik danışma, kuram ve uygulama (4. Baskı). Ankara: Vizetek Yayıncilık.

Ben-Zur, H. (2003). Happy adolescents: The link between subjective well-being, internal resources, and parental factors. Journal of Youth and Adolescence, 32(2), 67-79. https://doi.org/10.1023/a:1021864432505.

Büyüköztürk, Ş. (2011). Sosyal bilimler için veri analizi el kitabı (15. Baskı). Ankara: Pegem Akademi Yayıncilık.

Büyüköztürk, Ş., Kılıç Çakmak, E., Akgün, Ö. E., Karadeniz, Ş., \& Demirel, F.(2013). Bilimsel araştırma yöntemleri (14. Baskı). Ankara: Pegem Akademi Yayıncllık.

De Jong, P., \& Berg, I.K. (1998). Interviewing for solutions. Pacific Grove CA: Brooks/ Cole.

De Shazer, S., \& Berg I.K. (1997). 'What works?' Remarks on research aspects of solution-focused brief therapy. Journal of Family Therapy, 19, 121-124.

De Shazer, S. (1985). Keys to solution in brief therapy. New York: W.W. Norton\& Company Inc.

Diener, E. (1984). Subjective well-being, Psychological Bulletin, 95(3), 542-575. https://doi.org/10.1037/0033-2909.95.3.542.

Diener, E., \& Diener, C. (1996). Most people are happy. Psychological Science, 7(3), 181-185. 
Diener, E., Suh, E. M., Lucas, R. E., \& Smith, H. L. (1999). Subjective well-being: Three decades of progress. Psychological Bulletin, 125(2), 276-302. https://doi.org/10.1037/0033-2909.125.2.276.

Diener, E., Pressman, S. D., Hunter, J., \& Delgadillo-Chase, D. (2017). If, why, and when subjective well-being influences health, and future needed research. Applied Psychology: Health and Well-Being, 9(2), 133-167. https://doi.org/10.1111/aphw.12090.

Diener, E., Suh, E., \& Oishi, S. (1997). Recent findings on subjective well-being. Indian journal of Clinical Psychology, 24, 25-41.

Dubé, M., Lapierre, S., Bouffard, L., \& Alain, M. (2007). Impact of a personal goals management program on the subjective well-being of young retirees. Revue Européenne de Psychologie Appliquée/European Review of Applied Psychology, 57(3), 183-192. DOI:10.1016/j.erap.2005.04.004.

Ergin, D. A., Eren, N., \& Tatlı, C. (2020). Yetişkinlerde öznel iyi oluş düzeyini artırmaya yönelik hazırlanan yaratıcı drama temelli eğitim programının etkililiğinin sınanması. Yaratıcı Drama Dergisi, 15(1), 19-34. DOI: 10.21612/yader.2020.002.

Eryılmaz, A. (2014). Üniversite öğrencileri için geliştirilen öznel iyi oluşu artırma programının etkililiğinin incelenmesi. Mehmet Akif Ersoy Üniversitesi Ĕ̆itim Fakültesi Dergisi, 1(31), 111-128.

Eryılmaz, A.(2009) Ergen öznel iyi oluş ölçeğinin geliştirilmesi. Türk Eğitim Bilimleri Dergisi, 7(4), 975989.

Fitriyah, F. K. (2017). Reducing aggressive behavior using solution-focused brief counseling. JBKI (Jurnal Bimbingan Konseling Indonesia), 2(2), 34-39.

Hendar, K., Awalya, A., \& Sunawan, S. (2020). Solution-focused brief therapy group counseling to increase academic resilience and self-efficacy. Jurnal Bimbingan Konseling, 9(1), 1-7. https://doi.org/10.15294/jubk.v9i1.28494.

Iveson, C. (2002). Solution-focused brief therapy. Advances in Psychiatric Treatment, 8, 149-157. https://doi.org/10.1192/apt.8.2.149.

Karasar, N. (2016). Bilimsel araştırma yöntemi (31. Baskı). Ankara: Nobel Akademik Yayıncllık.

Karataş, Z. (2014). Psikodrama uygulamasının üniversite öğrencilerinin öznel iyi oluş ve umutsuzlukları üzerindeki etkisi. Eğitim ve Bilim, 39(173), 118-128.

Lethem, J. (2002). Brief solution focused therapy. Child and Adolescent Mental Health, 7(4), 189-192. https://doi.org/10.1111/1475-3588.00033.

Malkoç, A. (2011). Öznel iyi oluş müdahale programının üniversite öğrencilerinin öznel iyi oluş düzeylerine etkisi. Yayımlanmamış doktora tezi. Marmara Üniversitesi Eğitim Bilimleri Enstitüsü, Istanbul.

Murdock, N. L. (2012). Psikolojik danışma ve psikoterapi kuramları. (Çev. F. Akkoyun). Ankara: Nobel Akademik Yayıncllı.

Murphy, J. J. (1997). Solution-focused counseling in middle and high schools. Alexandria, VA: American Counseling Association. 
Myers, D. G., \& Diener, E. (1995). Who is happy?. Psychological Science, 6(1), 10-19.

Nedim Bal, P., \& Kaya, C. (2017). 6. sınıf öğrencilerinin okul tükenmişliği ile baş etmede çözüm odaklı grupla psikolojik danışmanın etkisi. Uluslararası Sosyal Araştırmalar Dergisi, 10(51), 769-777. http://dx.doi.org/10.17719/jisr.2017.1813.

Novriansyah, D., Purwanto, E., \& Wibowo, M. E. (2020). The effectiveness of solution-focused brief therapy group counseling to improve students' self-concepts. Jurnal Bimbingan Konseling, 9(2), 130-136. https://doi.org/10.15294/jubk.v9i2.31343.

O'Connell, B. (2001). Solution-focused stress counselling. London: Continuum.

Ryan, R. M., \& Deci, E. L. (2001). On happiness and human potentials: A review of research on hedonic and eudaimonic well-being. Annual Review of Psychology, 52(1), 141-166. http://dx.doi.org/10.1146/annurev.psych.52.1.141.

Rice, T. W., \& Steele, B. J. (2004). Subjective well-being and culture across time and space. Journal of Cross-Cultural Psychology, 35(6), 633-647. DOI: 10.1177/0022022104270107.

Ryff, C. D., \& Singer, B. (1998) The contours of positive human health, Psychological Inquiry, 9(1), 1-28. http://dx.doi.org/10.1207/s15327965pli0901_1.

Ryff, C. D. (1995). Psychological well-being in adult life. Current Directions in Psychological Science, 4(4), 99-104. http://dx.doi.org/10.1111/1467-8721.ep10772395.

Ryff, C. D., \& Singer, B. (1996). Psychological well-being: Meaning, measurement, and implications for

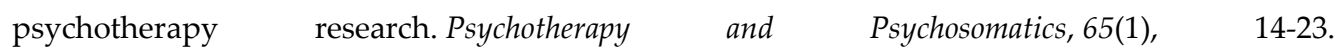
http://dx.doi.org/10.1159/000289026.

Ryff, C. D., \& Singer, B. H. (2008). Know thyself and become what you are: A eudaimonic approach to

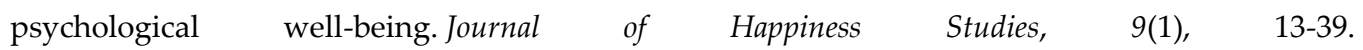
http://dx.doi.org/10.1007/s10902-006-9019-0.

Sağkal, A. S., \& Türnüklü, A. (2017). Barış eğitimi programının lise öğrencilerinin öznel iyi oluş ve umut düzeyleri üzerindeki etkileri. Türk Psikolojik Damışa ve Rehberlik Dergisi, 7(47), 69-85.

Saito, T., Kai, I., \& Takizawa, A. (2012). Effects of a program to prevent social isolation on loneliness, depression, and subjective well-being of older adults: A randomized trial among older migrants in Japan. Archives of Gerontology and Geriatrics, 55(3), 539-547. http://dx.doi.org/10.1016/j.archger.2012.04.002.

Sarı, E., \& Günaydın, N. (2016). Çözüm odaklı depresyon ile başa çıkma eğitiminin depresyon belirtileri üzerindeki etkileri. Anadolu Psikiyatri Dergisi, 17(5). 369-375. DOI: 10.5455/apd.208951.

Sarvi, Z., \& Ghazi, M. E. (2016). Effectiveness of group counseling with solution focused (brief) therapy (SFBT) on increasing self-efficacy of fifth grade primary school female students. Modern Applied Science, 10(12), 1-6. http://dx.doi.org/10.5539/mas.v10n12p1.

Schimmack, U., Radhakrishnan, P., Oishi, S., Dzokoto, V., \& Ahadi, S. (2002). Culture, personality, and subjective well-being: Integrating process models of life satisfaction. Journal of Personality and Social Psychology, 82(4), 582-593. https://doi.org/10.1037/0022-3514.82.4.582. 
Setiono, L., Marjohan, M., \& Marlina, M. (2019). Implementation of solutions-focused counseling (SFC) to improve student motivation: A single subject research. Journal of ICSAR, 3(1), 8-14. https://doi.org/10.17977/um005v3i12019p008.

Shapiro, A., \& Taylor, M. (2002). Effects of a community-based early intervention program on the subjective well-being, institutionalization, and mortality of low-income elders. The Gerontologist, 42(3), 334-341.

Sparrer, I. (2012). Çözüm odaklı yaklaşıma ve sistemik yapısal dizime giriş (Çev. E. Suvarierol). İstanbul: Pan Yayıncilik.

Springer, K. W., \& Hauser, R. M. (2006). An assessment of the construct validity of Ryff's scales of psychological well-being: Method, mode, and measurement effects. Social Science Research, 35(4), 1080-1102. http://dx.doi.org/10.1016/j.ssresearch.2005.07.004.

Tov, W., \& Diener, E. (2007). Culture and subjective well-being. In S. Kitayama \& D. Cohen (Eds.), Handbook of Cultural Psychology (pp. 691-713). New York: Guilford.

Yılmaz Bingöl, T., \& Akın, A. (2018). Çözüm odaklı kısa süreli yaklaşıma dayalı grup rehberliği programının öz-yeterlik inancına etkisi. OPUS-Uluslararası Toplum Araştırmaları Dergisi, 8(14), 321-340. DOI: 10.26466/opus.406195. 